\title{
Interpreting the historical terrestrial vertebrate biodiversity of Cayman Brac (Greater Antilles, Caribbean) through collagen fingerprinting
}

DOI:

10.1177/0959683618824793

\section{Document Version}

Accepted author manuscript

Link to publication record in Manchester Research Explorer

Citation for published version (APA):

Harvey, V., Egerton, V., Chamberlain, A., Manning, P., Sellers, W. I., \& Buckley, M. (2019). Interpreting the historical terrestrial vertebrate biodiversity of Cayman Brac (Greater Antilles, Caribbean) through collagen fingerprinting. The Holocene. https://doi.org/10.1177/0959683618824793

\section{Published in:}

The Holocene

\section{Citing this paper}

Please note that where the full-text provided on Manchester Research Explorer is the Author Accepted Manuscript or Proof version this may differ from the final Published version. If citing, it is advised that you check and use the publisher's definitive version.

\section{General rights}

Copyright and moral rights for the publications made accessible in the Research Explorer are retained by the authors and/or other copyright owners and it is a condition of accessing publications that users recognise and abide by the legal requirements associated with these rights.

\section{Takedown policy}

If you believe that this document breaches copyright please refer to the University of Manchester's Takedown Procedures [http://man.ac.uk/04Y6Bo] or contact uml.scholarlycommunications@manchester.ac.uk providing relevant details, so we can investigate your claim.

\section{OPEN ACCESS}




\title{
Interpreting the Historical Terrestrial Vertebrate Biodiversity of Cayman Brac (Greater Antilles, Caribbean) through Collagen Fingerprinting
}

\author{
Virginia L. Harvey ${ }^{1}$. Victoria M. Egerton ${ }^{1}$. Andrew T. \\ Chamberlain ${ }^{1}$. Phillip L. Manning ${ }^{1}$. William I. Sellers ${ }^{1}$. Michael \\ Buckley ${ }^{1}$.
}

${ }^{1}$ School of Earth and Environmental Sciences, University of Manchester, Manchester, M13 9PL, United Kingdom

\section{Abstract}

Cayman Brac (Cayman Islands) lies within the Caribbean Islands Biodiversity Hotspot, an epicenter of high biodiversity and endemism. However, all endemic terrestrial mammals on the Cayman Islands are now extinct, following post-1500 AD human colonization of the islands. Introduced rodents and domesticated mammals now exclusively represent this facet of terrestrial fauna on the Cayman Islands, and are a likely cause of endemic species loss on the islands. Cayman Brac has numerous caves and rock fissures that offer protection to a naturally accumulated ensemble of vertebrate sub-fossil bone remains, documenting modifications in island biodiversity through the Holocene. In this study we showcase the first molecular faunal survey undertaken on subfossil remains from the Cayman Islands, using collagen fingerprinting for taxonomic identification of the cave skeletal deposits collected from a single cave system, Green Cave on Cayman Brac. Collagen type (I) extracts from 485 bone fragments were analyzed to determine faunal identity and assemblage composition. A total of $76 \%$ of the collagen fingerprint-yielding samples were mammalian in origin, $67 \%$ of which were identified as invasive murid rodents. Here, we present mass spectral biomarkers for the endemic terrestrial mammal fauna of Cayman Brac, including the extinct capromyid rodents, Capromys and Geocapromys (Rodentia: Capromyidae), alongside commentary on the composition of the sub-fossil bone assemblage between the five distinct depositional chambers that comprise Green Cave. Collagen (I) provides a key service in taxonomic identification and mapping of macroevolutionary trends and these results suggest a pivotal role for murid rodents in the competition and extinction of terrestrial endemic mammals from the Cayman Islands. 


\section{Key Words}

Collagen fingerprinting; ZooMS; Species identification, Caribbean; Cayman Islands; Paleobiodiversity

\section{Introduction}

\section{Extinction in the Caribbean}

Insular ecosystems in the Caribbean have undergone considerable anthropogenic modifications over the last 7,000 years (Fitzpatrick and Keegan, 2007; Wilson, 2007; Fitzpatrick, 2015). Humans have altered habitats causing a localized mass extinction in the Caribbean Islands Biodiversity Hotspot (CIBH) (Brooks et al., 2002; Steadman et al., 2005; Fitzpatrick and Keegan, 2007; Wilson, 2007; Upham, 2017). The ClBH archipelago comprises over 1,000 habitat-rich islands and is one of the world's greatest centers for biodiversity and endemism that is under unprecedented threat (Myers et al., 2000) (Figure 1). In the last 500 years, $90 \%$ of primary vegetation in the CIBH has been affected by deforestation and urban encroachment, and over 40 endemic species have become extinct (Brooks et al., 2002; Anadón-Irizarry et al., 2012). The vertebrate class most affected by this extinction event in the $\mathrm{CIBH}$ are mammals, with more than 100 volant and non-volant species identified as becoming extinct or extirpated during the Holocene ( 11,700 years ago-present) (Steadman et al., 2005; Steadman et al., 2007; Turvey et al., 2007; Turvey and Fritz, 2011). The specific drivers of these events are difficult to quantify, although direct (e.g. habitat transformation, hunting) and indirect human activities (e.g. species introduction) are suggested to have been major factors driving the CIBH extinctions (Giovas et al., 2012; Cooke et al., 2017). As a consequence, this biodiversity hotspot is the source of the highest levels of recent mammal species loss in the world (Dávalos and Turvey, 2012). 


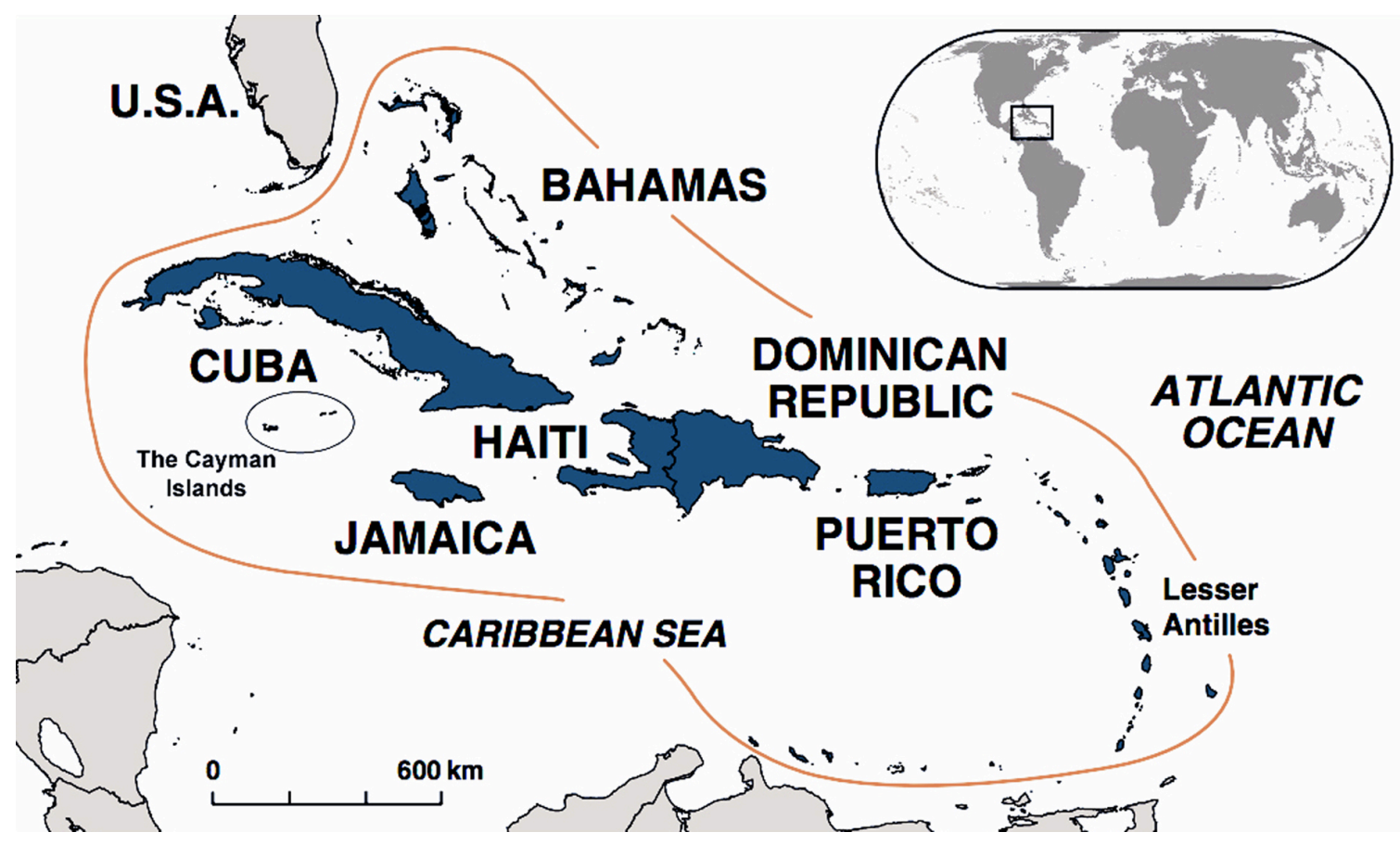

Figure 1: The location of the Cayman Islands within the Caribbean Island Biodiversity Hotspot (CIBH; solid red line). Adapted from Smith et al. (2004).

Located within the $\mathrm{ClBH}$, the Cayman Islands (British Overseas Territory) consist of three main islands: Grand Cayman, Little Cayman and Cayman Brac. These islands are unique in their geographical and temporal isolation within the Caribbean, being 200 km ( 125 $\mathrm{mi}$ ) from any other substantive landmass. Remarkably, the Cayman Islands have had little to no anthropogenic influences until 1503, following their discovery by Columbus (Stokes and Keegan, 1996; Drewett et al., 2000). Historical records of the Cayman Islands from early European settlers speak of ample natural resources comparable to that of other Caribbean islands that are known to have hosted indigenous populations (Drewett et al., 2000). Additionally, whilst the distance required to reach the Cayman Islands from neighboring islands is notably the longest journey in the Caribbean, Drewett et al. (2000) conclude that it is "not significantly greater than from Jamaica to Cuba, St Vincent to Barbados or Venezuela to Los Roques" - all crossings known to have been made by indigenous people in prehistory. Yet, targeted surveys and excavations made by Stokes and Keegan (1996) and Drewett et al. (2000), in addition to faunal surveys from Patton (1966), Morgan (1994a) and this study, have revealed no evidence of human occupation in the Prehistoric Period. Furthermore, there is no record of permanent settlement on the Cayman Islands until the middle of the $17^{\text {th }}$ century (Williams, 1992; Smith, 2000), thousands of years after humans first settled other Caribbean islands (Fitzpatrick and Keegan, 2007). Hereafter, humans have played a dominant role influencing terrestrial vertebrate composition through habitat alteration, predation and invasive species introduction; the latter of which is suggested to have been a key factor in Cayman biodiversity loss over the last five hundred years (Morgan, 1994a). 


\section{Cayman Island Caves}

The Cayman Islands are composed of carbonate platforms that have been shaped through eustatic sea level change since the Miocene (Jones, 1992). Cayman Brac, the larger ( $38 \mathrm{~km}^{2}$ ) of the two sister islands to Grand Cayman, has been subject to repeated periods of cave development over the last 30 million years (Ma), resulting in numerous Karst limestone systems and cavities that typify the island (Jones, 1992). These cave systems are host to a natural, temporally accumulated sub-sample of the Cayman Brac vertebrate community through the deposition of bones via transportation, natural traps, carnivore (e.g. Tyto alba, barn owl) accumulation and habitation (Morgan, 1994a). Many of the Cayman cave sub-fossils are also encased in calcareous flowstone, with these factors working synergistically to limit morphological identification, thereby reducing the usefulness of large parts of the assemblages for morphology-based faunal surveys.

The cave sub-fossil assemblages document modifications in island biodiversity spanning the Holocene, encompassing the timeline traversing pre-human interaction through to the modern day. However, the sub-fossil remains on Cayman Brac, and indeed all of the Cayman Islands, have been vastly understudied. Primary investigations into the vertebrate skeletal deposits from cave systems on the Cayman Islands began with Moyne (1938), who target-collected large sub-fossils from the surface of some caves on Grand Cayman and Cayman Brac, never collecting microvertebrate remains or excavating stratigraphic layers beneath present cave floors. Later studies on Cayman Island fauna are scarce, with the vast majority focusing mainly on mammals (Morgan and Woods, 1986; Morgan, 1994a; Morgan, 1994b; MacPhee et al., 1999). Moreover, all previous sub-fossil examinations on Cayman Brac have relied exclusively on bone morphology to undertake species identification. Yet, such a process of identification neglects to utilize the wealth of fragmented and heavily calcified material that represents much of the Island fossil vertebrate assemblages and has, until now, remained an untapped resource for biodiversity data.

The extinct endemic terrestrial (i.e. non-volant, non-marine) mammal fauna of Cayman Brac consist of three undescribed species previously identified from the sub-fossil deposits: the large capromyid rodent Capromys sp., the smaller capromyid Geocapromys sp., and one species of the evolutionarily distinct and globally extinct shrew-like eulipotyphlan, Nesophontes sp. (Morgan, 1994a) (see Supplementary Table S1). However, the terrestrial mammal fauna in present day Cayman Brac is wholly represented by three species of introduced rodents: the black rat, Rattus rattus; the brown or Norway rat, Rattus norvegicus; and the house mouse, Mus musculus (Morgan, 1994b), alongside introduced domesticates. This extensive modification in island biodiversity on Cayman Brac is therefore particularly apparent within the Rodentia, but it should also be noted that certain bats (four species) and birds (nine species) have 
become extinct or extirpated on Cayman Brac in modern times (Morgan, 1994a; GISD, 2016). Fortunately, all taxonomically described herpetofaunal species have thus far escaped extinction on Cayman Brac, though the two native amphibian species Osteopilus septentrionalis and Eleutherodactylus planirostris may be under threat by the possible introduction of Rhinella marina (the cane toad) which is particularly famed for its opportunistic feeding and prolific breeding habits (Echternacht et al., 2011). Similarly, there have been six reptile species introduced within the last 70 years (Echternacht et al., 2011), joining the 14 endemic and native species known to Cayman Brac (Supplementary Table S1).

Despite the high number of introduced species on Cayman Brac, little research has been undertaken to investigate their impact, regardless of the fact that invasive species introductions are thought to be the leading cause of endemic species loss on both the Cayman Islands and other islands in the Caribbean. Biodiversity surveys and observational methods of sampling are no longer viable for extinct fauna, and morphological identification requires both expertise and relatively non-fragmentary material, particularly when dealing with post-cranial elements (e.g. Andrews, 1990). Rather, faunal identification of sub-fossils through biomolecular techniques such as collagen fingerprinting remains a useful alternative. Such an approach has the potential to yield clearly defined molecular-based species identification alongside presence/abundance data to compare with modern day Cayman Brac. These data are vital in the assessment of past and present island biodiversity, which can be utilized to further measure the overall health of the extant ecosystem.

\section{Collagen Fingerprinting}

Bone collagen type I (hereafter 'collagen (I)'), has a complex four-tiered hierarchical organization, locked within mineral hydroxyapatite. Collagen (I) survives both high temperatures and long-term burial far longer than that of other biologically informative proteins, such as ancient DNA (aDNA). Successfully extracted from ancient camel bone of $3.5 \mathrm{Ma}$ (Rybczynski et al., 2013), collagen (I) is the most abundant protein in animals and is therefore often selectively enriched in archaeological bones due to faster degradation of other bone proteins (Schmidt-Schultz and Schultz, 2004). Taxonomic identification via collagen fingerprinting can often provide greater confidence than visual identification can provide (e.g. Buckley and Kansa, 2011), particularly when identifying fragmentary material or microvertebrate mammal remains from owl pellets-a notoriously challenging task, even when pellets are fresh (Matisoo-Smith and Allen, 2001; Guimaraes et al., 2016).

The Cayman Brac cave systems offer refuge from environmental extremes (temperature fluctuations, humidity, salinity etc.) with subterranean systems aiding the preservation of vertebrate remains far beyond that which would be expected from a typical site in the tropics (Harvey et al., 2016). This excellent preservation permits the survival of 
informative biomolecules such as collagen (I), from which faunal identification (e.g. Buckley et al., 2014), temporal frameworks (Harvey et al., 2016) and phylogenetic information (e.g. Buckley, 2013) can be deduced. Collagen (I) chains are large and evolve at a slow rate, allowing soft-ionization methods of mass spectrometry (MS) to identify discrimination in the mass-to-charge $(\mathrm{m} / \mathrm{z})$ ratios of distinct collagen peptides, or 'biomarkers', between taxa across the animal kingdom. It is due to the relative resistance of collagen to degradation and its amino acid sequence variability between (Buckley et al., 2010; Buckley et al., 2017) and occasionally within genera (Buckley et al., 2016), that collagen (I) provides a key service in taxonomic identification and the reconstruction of molecular-based phylogenies and mapping of macroevolutionary trends.

This study aims to assess the ability of a high-throughput form of collagen fingerprinting (Zooarchaeology by Mass Spectrometry; ZooMS), to determine the faunal identity of 485 partial, fragmented and/or flowstone-encased bone remains from Green Cave, Cayman Brac, in the absence of morphological expertise. Within this remit, ZooMS, supported by peptide sequencing using liquid chromatography tandem mass spectrometry (LC-MS/MS), was deployed on modern and ancient specimens-including Caribbean representatives from mammalian, reptilian, avian and amphibian clades-to acquire collagen (I) peptide mass fingerprints (PMFs), and verify species collagen (I) biomarker sequences in the creation of a 'reference library' for Cayman Brac sub-fossil vertebrate assemblages. Such a reference library is also applicable for use across the Cayman Islands, throughout the Caribbean and key biomarkers are likely to be applicable elsewhere globally. This research presents the use of ZooMS in evaluating the faunal composition of a Cayman Island sub-fossil assemblage and explores the potential for applying the ZooMS methodology to other archaeological and paleontological sites in the Caribbean and beyond.

\section{Materials and Methods}

\section{Location}

The Cayman Islands are sites of great scientific interest due to their historical isolation yet present-day ease of access. Cayman Brac $\left(19^{\circ} 43^{\prime} \mathrm{N}, 79^{\circ} 47^{\prime} \mathrm{W}\right)$ has been chosen for this study due to its relatively low levels of urbanization (in comparison to Grand Cayman) and numerous cave systems, the majority of which remain relatively untouched, unexplored and unexcavated. This study focuses on Green Cave $\left(19^{\circ} 43^{\prime} 9^{\prime \prime} \mathrm{N}\right.$, $\left.79^{\circ} 44^{\prime} 4^{\prime \prime} \mathrm{W}\right)$, chosen because of its five large, distinct chambers and the relatively large quantity of sub-fossil remains contained within each. The cliff entrance to Green Cave is on the south face of the limestone plateau termed 'The Bluff', $22 \mathrm{~m}(+/-1-5 \mathrm{~m})$ above sea level, which connects to a series of passages and chambers that ends in a large chamber that opens to the top of The Bluff. The chambers do not exceed $1.5 \mathrm{~m}$ in height and the whole cave system developed through solutional widening of joint systems 
within a single bedding plane. Chamber 1 is positioned closest to the cave entrance on The Bluff; chamber 5 extends northerly, towards the center of the island. The cave system was mapped in 3D using a portable LiDAR scanner (Z\&F Imager 5006i), and converted to plan view (Figure 2).

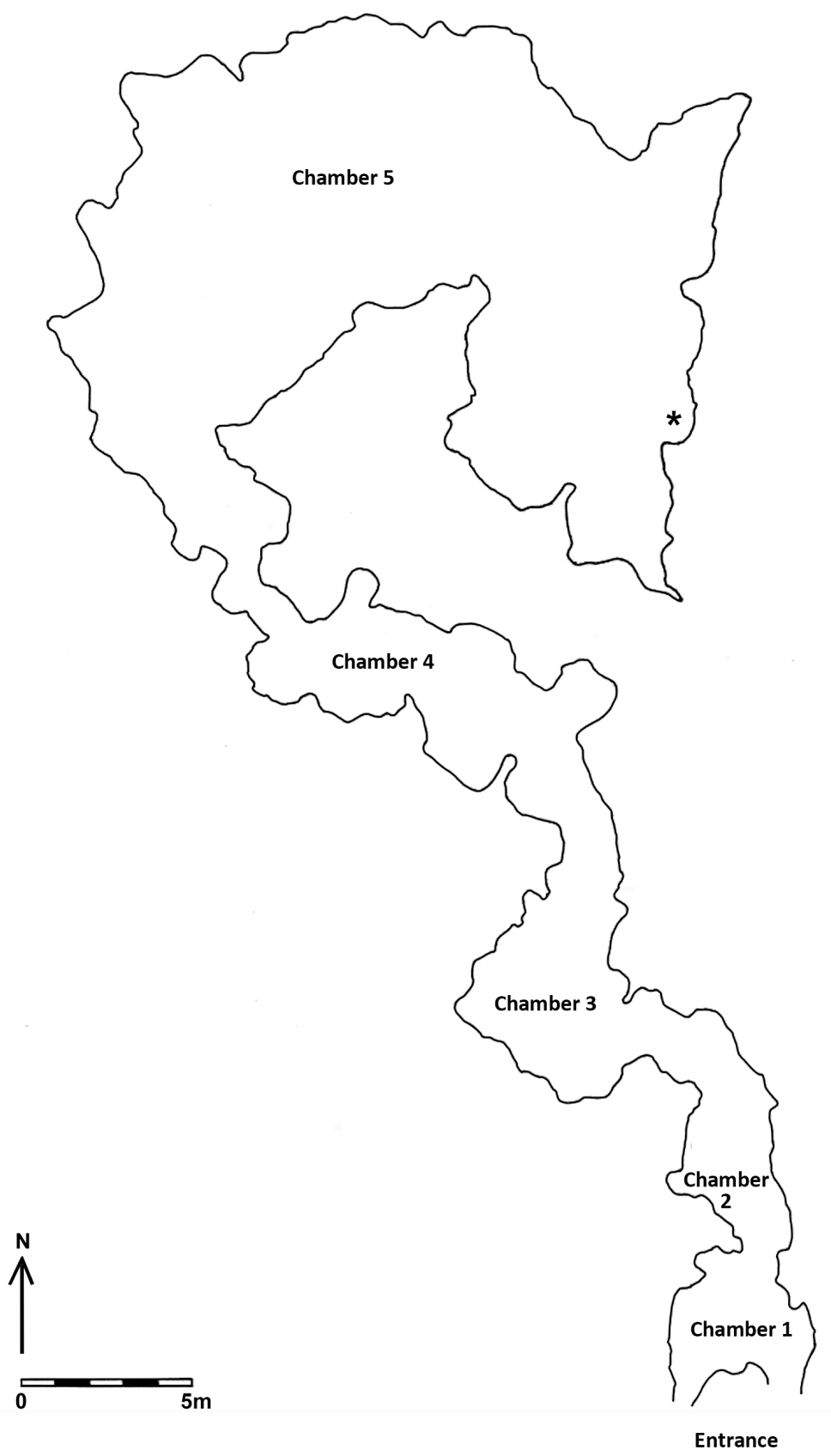

Figure 2: Map of Green Cave (Cayman Brac) depicting each of the five chambers and site of a $60 \times 75 \mathrm{~cm}$ excavation (*). 


\section{Sample Collection}

A total of 485 bone samples collected from Green Cave were examined in this study (Supplementary Table S2). Bone material was collected from the cave floor surface sediments of each of the five chambers. These sediments (Table 1) consist of partially cemented fine-grained colluvial deposits containing rounded limestone clasts, shell fragments and bones. The limestone clasts are most likely rounded from chemical weathering that is typical of sediments formed on karstified limestones in Mediterranean and tropical climates (Wright and Wilson, 1987). The amount of sample material collected was dependent upon two factors: (i) relative chamber size, and (ii) accessibility of the chambers (i.e. where roof height restricted collection). Additionally, a small pit was excavated against the eastern wall of chamber 5 , the northernmost chamber (see Figure 2), between two prominent stalagmite buttresses. The pit measured approximately $60 \mathrm{~cm} \mathrm{E-W} \mathrm{by} 75 \mathrm{~cm} \mathrm{~N}-\mathrm{S}$ and was hand-excavated down to the limestone cave floor, $35 \mathrm{~cm}$ below the current cave floor. Remains were mapped and removed from each depositional context for analysis (Table 1).

Table 1: Summary of depositional contexts representing natural stratigraphic layers of the pit excavated in chamber 5, Green Cave (Cayman Brac).

\begin{tabular}{|c|c|c|}
\hline Context & Depth $(\mathrm{cm})$ & Description \\
\hline 0 & $0-5$ & $\begin{array}{l}\text { Unconsolidated surface deposits consisting of fine silts } \\
\text { with rounded limestone clasts and fragments of mollusc } \\
\text { and crustacean shells. Skeletal remains collected from } \\
\text { loose surface sediments }\end{array}$ \\
\hline 1 & $5-15$ & Solid stalagmite floor (no skeletal collection possible) \\
\hline 2 & $15-20$ & Cemented stone and shell deposits \\
\hline 3 & $20-25$ & Terra rossa sediments with root penetration \\
\hline 4 & $25-35$ & Shelly breccia \\
\hline- & $>35$ & Limestone floor to cave (solid geology) \\
\hline \multicolumn{3}{|c|}{ ZooMS Collagen Fingerprinting } \\
\hline \multicolumn{3}{|c|}{$\begin{array}{l}\text { Chemicals were procured according to Buckley et al. (2014) and collagen (I) peptide } \\
\text { mass fingerprints (PMFs) were obtained using methods modified from Buckley et al. } \\
\text { (2016) whereby } 485 \text { sub-fossil bone fragments from Green Cave (a selection comprising } \\
\text { examples from each chamber and context) were demineralized in } 1 \mathrm{~mL} 0.6 \mathrm{M} \\
\text { hydrochloric acid }(\mathrm{HCl}) \text { at } 4{ }^{\circ} \mathrm{C} \text { for } 18 \mathrm{~h} \text { to extract soluble collagen (I). Where heavy }\end{array}$} \\
\hline
\end{tabular}


geological matrix encased bone samples, $1 \mathrm{~mL} 0.6 \mathrm{M} \mathrm{HCl}$ was added for several minutes until the calcareous matrix finished reacting. The acid was then replaced with $1 \mathrm{~mL}$ fresh $0.6 \mathrm{M} \mathrm{HCl}$, and samples were treated as above. Larger bone samples were drilled to remove $25 \mathrm{mg}$ of matrix-free bone powder. Following demineralization, the supernatant was ultrafiltered at $3700 \mathrm{rpm}$ for 30 min using 96-well $30 \mathrm{kDa}$ molecular weight cut-off (MWCO) plates, washed with $0.8 \mathrm{~mL} 50 \mathrm{mM}$ ammonium bicarbonate $(A B C)$, re-suspended in $100 \mu \mathrm{L} 50 \mathrm{mM} \mathrm{ABC}$ and digested with $0.3 \mu \mathrm{g}$ sequencing-grade trypsin for $18 \mathrm{~h}$ at $37^{\circ} \mathrm{C}$. Digested samples were diluted into $10 \mathrm{mg} / \mathrm{mL} \alpha$-cyano-4hydroxycinnamic acid matrix solution and $2 \mu \mathrm{L}$ spotted onto a 384-well Bruker Ultraflex target plate and air-dried following Buckley et al. (2016). A Bruker Ultraflex II MALDI mass spectrometer (MS) was utilized at up to 5000 laser shots per plate spot over a $\mathrm{m} / \mathrm{z}$ range of 700-3700 and against five calibrant peptides. Resultant PMFs were analyzed using mMass software (v5.5.0). Where PMFs from the soluble collagen did not denote a clear faunal identification, the acid-insoluble pellets that remained following demineralization were then treated with $300 \mu \mathrm{L} 50 \mathrm{mM} \mathrm{ABC}$ and gelatinized at $65^{\circ} \mathrm{C}$ for $18 \mathrm{~h}$ to extract insoluble collagen (I) before being analyzed as above and fractionated following Buckley et al. (2009).

Reference specimens (Nesophontes major, Capromys pilorides, Geocapromys brownii, Dasyprocta punctata, Macrotus waterhousii, Erophylla sezekorni, Eptesicus fuscus, Tadarida brasiliensis, Agalychnis callidryas, Bufo viridis, Larus canus and Cyclura sp.; see Supplementary Table S3) were demineralized in $1 \mathrm{~mL} 0.6 \mathrm{M} \mathrm{HCl}$ at $4{ }^{\circ} \mathrm{C}$ for $6 \mathrm{~h}$, briefly centrifuged, and the supernatant applied to singular $10 \mathrm{kDa}$ MWCO ultrafilter units. Samples were washed twice $(0.5 \mathrm{~mL})$ and collected $(100 \mu \mathrm{L})$ with $50 \mathrm{mM} \mathrm{ABC}$ prior to digestion with $0.4 \mu \mathrm{g}$ trypsin at $37^{\circ} \mathrm{C}$ for $18 \mathrm{~h}$. Reference samples were then purified and fractioned via $\mathrm{C} 18$ solid phase extraction pipette tips following methods detailed in Buckley et al. (2009) whereby samples were acidified to $0.1 \%$ trifluoroacetic acid (TFA), washed twice on the $\mathrm{C} 18$ pipette tip column with $100 \mu \mathrm{L} 0.1 \%$ TFA and transferred to a stepped gradient of $10 \%$ and $50 \%$ acetonitrile (ACN) in $0.1 \%$ TFA concentrations to elute the peptides. Fractions were dried and re-suspended in $10 \mu \mathrm{L} 0.1 \%$ TFA before $1 \mu \mathrm{L}$ of each fraction was applied to the target plate and analyzed using MS as above.

\section{LC-MS/MS}

Liquid chromatography tandem mass spectrometry (LC-MS/MS; Waters nanoAcquity UPLC system coupled to a Thermo Scientific Orbitrap Elite mass spectrometer) was carried out on reference samples through methodology modified from Buckley et al. (2015), whereby $10 \%$ and $50 \%$ fractions were combined, dried and re-suspended in $5 \%$ $\mathrm{ACN}+0.1 \%$ formic acid (FA). Samples were then concentrated on a pre-column $(20 \mathrm{~mm}$ $\times 180 \mu \mathrm{m}$ ) and separated on a $1.7 \mu \mathrm{M}$ Waters nanoAcquity Ethylene Bridged Hybrid (BEH) C18 analytical column of $75 \mathrm{~mm} \times 250 \mu \mathrm{m}$ i.d., using a gradient starting from $99 \%$ buffer $A / 1 \%$ buffer $B$ and finishing on $75 \%$ buffer $A / 25 \%$ buffer $B$ in 45 min at $200 \mathrm{~nL}$ $\min ^{-1}$, where buffer $A=0.1 \% F A$ in $\mathrm{H}_{2} \mathrm{O}$ and buffer $B=0.1 \% \mathrm{FA}$ in $A C N$. Resultant $\mathrm{MS} / \mathrm{MS}$ 
data files were initially searched against publically available protein sequence database, SWISS-PROT, to ensure all samples predominantly contained the collagen (I) protein. MS/MS data files were then subjected to standard searches of all significant protein families using MASCOT (v2.5.1; Cottrell and London, 1999) against a custom (local) database of collagen (I) sequences created through manual collagen (I) sequence acquisition of relevant species from 'Protein BLAST' (Basic Local Alignment Search Tool; BLAST/P) (see Supplementary Table S4 for species list). Standard error tolerant searches, detailed in Buckley et al. (2015), were undertaken to highlight any potential sequence variations between the MS/MS data and the collagen (I) sequences in the custom database. Proposed homologous species-specific peptide sequences for each reference specimen were manually examined for quality based upon assigned ion scores and the assessment of fragment ion spectra. Standard MASCOT 'decoy' searches defined in Buckley et al. (2015) were then employed to further interrogate ion fragmentation matches. False positive peptide matches were assessed and assigned ion scores and matched peptides were then filtered to remove peptides with an ion score lower than the highest score for any false positive match. Fragment ion spectra were checked against the relevant $\mathrm{PMF}$ and where a peak was visible $\left(\mathrm{M}+\mathrm{H}^{+} \mathrm{m} / z\right)$, the peptide and sequence was recorded as a biomarker for this species. Collagen (I) biomarkers were labeled following the system outlined in Buckley et al. (2009) whereby unique coding refers a peptide to a specific section in the collagen (I) sequence. For example, peptide COL1A1T47 represents collagen (I) $\alpha 1$ tryptic peptide number 47 (see Buckley, 2016 for complete sets described for cow, sheep and pig).

\section{Results}

\section{Collagen (I) Peptide Biomarkers}

Of the 485 sub-fossil bone samples selected for ZooMS analysis from Green Cave (Cayman Brac), a total of 260 (54\%) generated collagen (I) peptide mass fingerprints (PMFs) that were suitable for biomolecular identification-a reasonable result considering the tropical climate of the deposition locality. The remainder of the samples produced 'failed' fingerprints, characterized by $<10$ peaks above $\mathrm{m} / z 1500$ following a signal-to-noise (S/N) filter of 5.0, following Harvey et al. (2016).

Almost all samples in this study can be separated initially into vertebrate class (Mammalia, Amphibia, or Reptilia [birds and reptiles]) using a single peptide biomarker, COL1A1T47. This biomarker is known to be present at $m / z 1105$ in the PMFs of terrestrial mammals (amino acid sequence GVQGPPGPAGPR) (Buckley et al., 2014) and its homologous peptide is observed at $m / z 1108$ or $m / z 1134$ in the modern amphibians tested (sequences GAQGPPGPQGAR and GAQGPPGPQGPR respectively) and at $m / z$ 1162 in the majority of reptiles and birds of taxonomic relevance to this study (sequence GVQGPPGPQGPR; Supplementary Figures S1-3). Unexpectedly in iguanids, both the reference sample of the ground iguana Cyclura sp. and Sample 71 (suspected iguanid) 
display the COL1A1T47 biomarker at $\mathrm{m} / \mathrm{z}$ 1105-identical in mass to terrestrial mammals (Supplementary Figure S2). LC-MS/MS data confirms the peptide sequence for iguanids is GVQGPAGPPGPR, which is isobaric to the terrestrial mammal version of the biomarker, but not identical in sequence. Another prominent PMF biomarker common to both Cyclura sp. and Sample 71 (the iguanids) can be viewed at $m / z 1393$, representing peptide COL1A1T28 and sequence GEPGPAGLPGPAGER. This peptide is also common to the avian reference taxon from Reptilia, Larus canus (common gull), and we conclude this as a viable marker with which to separate the Reptilia (including iguanids) from Mammalia in this study, although it is worthy of noting that outside of this study area not all Reptilia share the same peptide sequence for COL1A1T28, and hence can have different masses (e.g. Python bivittatus, Supplementary Table S4.7).

Through the process of PMF examination coupled with LC-MS/MS data analysis we propose that 17 collagen (I) peptide biomarkers are the minimum required to distinguish all vertebrate fauna on Cayman Brac, which includes the refinement of all terrestrial mammals to species-level (Figure 3). (See also Supplementary Table S4 and Supplementary Figures S5-S18 for details of the peptide sequences for these biomarkers.) 


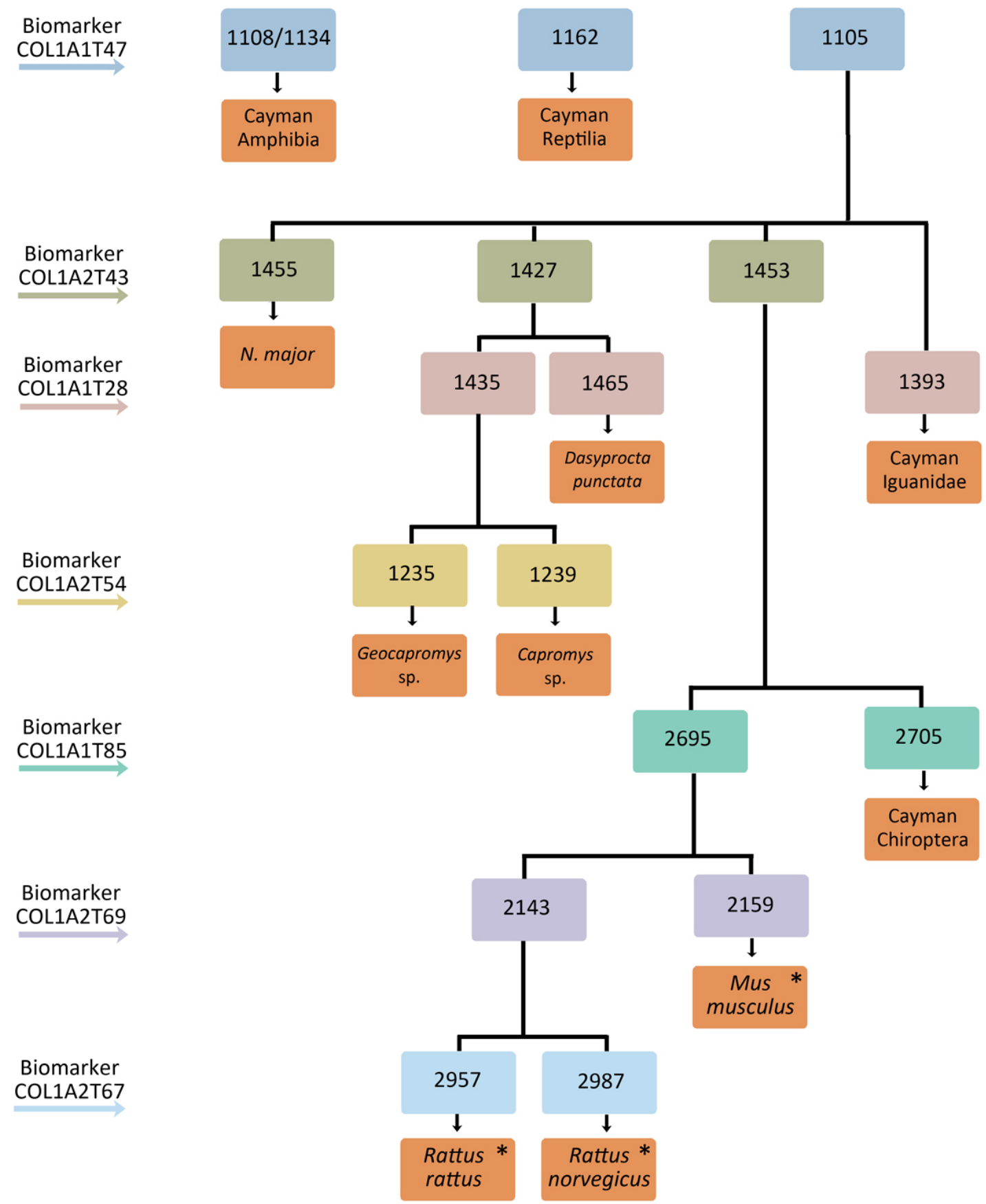

Figure 3: Flow chart depicting the minimum collagen (I) peptide biomarkers required for the identification of all ancient bone samples in this study. Note: outside of this study these biomarker pathways must be used with caution (see text). *Species-specific biomarkers from Buckley et al. (2016). NB: the COL1A2T43 biomarker for iguanids remains unidentified from the PMF and LC-MS/MS data due to a lack of published sequence information and thus is not included. 
All extinct and extant terrestrial mammals (non-marine, non-volant) on Cayman Brac can be refined to species level assuming the minimum biomarkers required for this task are visible in the PMF. Additionally, the chiropterans (volant taxa) can be confidently separated out at order level. However, it should also be noted that other vertebrate fauna present outside of the Cayman Islands might have the same marker pathways as those used here. For example, we use $m / z 1105+1453+2705$ as a set of markers specific to all chiropterans in this study but are well aware that they are observed in fauna found outside of the Cayman Islands (e.g., some carnivores as well as pig; Buckley et al., 2009; Buckley, 2016). Additionally, in this assemblage all samples identified as Reptilia, with the exception of Cyclura sp., display a peak at $m / z 1162$, although this peptide is highly variable in sequence on a global level and is not present at $m / z 1162$ in all birds and reptile PMFs (see Supplementary Table S4.2).

\section{Faunal Identifications}

Biomarker acquisition permitted the identification of Cayman Brac bone samples down to the following lowest-level designations: species $(n=159)$, genus $(n=28)$, family $(n=10)$, order $(n=1)$ and class ( $n=62)$ (Figure 4$)$. Therefore, the majority $(61 \%)$ of successfully fingerprinted sub-fossil bones are identifiable to species level. Of these, 198 are mammals (65 Capromys sp.; 132 Muridae; 1 Chiroptera), 40 samples are Amphibia and 22 are Reptilia (reptiles/birds). There appear to be no occurrences of the introduced Central American red agouti, Dasyprocta punctata, nor the endemic and extinct hutia, Geocapromys sp., or basal eutherian, Nesophontes sp., in the assemblage. There are also no specific identifications of the brown rat ( $R$. norvegicus) or the house mouse ( $M$. musculus) from the Green Cave sub-fossil remains, though their presence within the ten samples identified only to 'Muridae', cannot be ruled out. This is due to an absence of species-specific biomarkers in the PMFs, most likely as a consequence of poorer collagen integrity in these samples. 


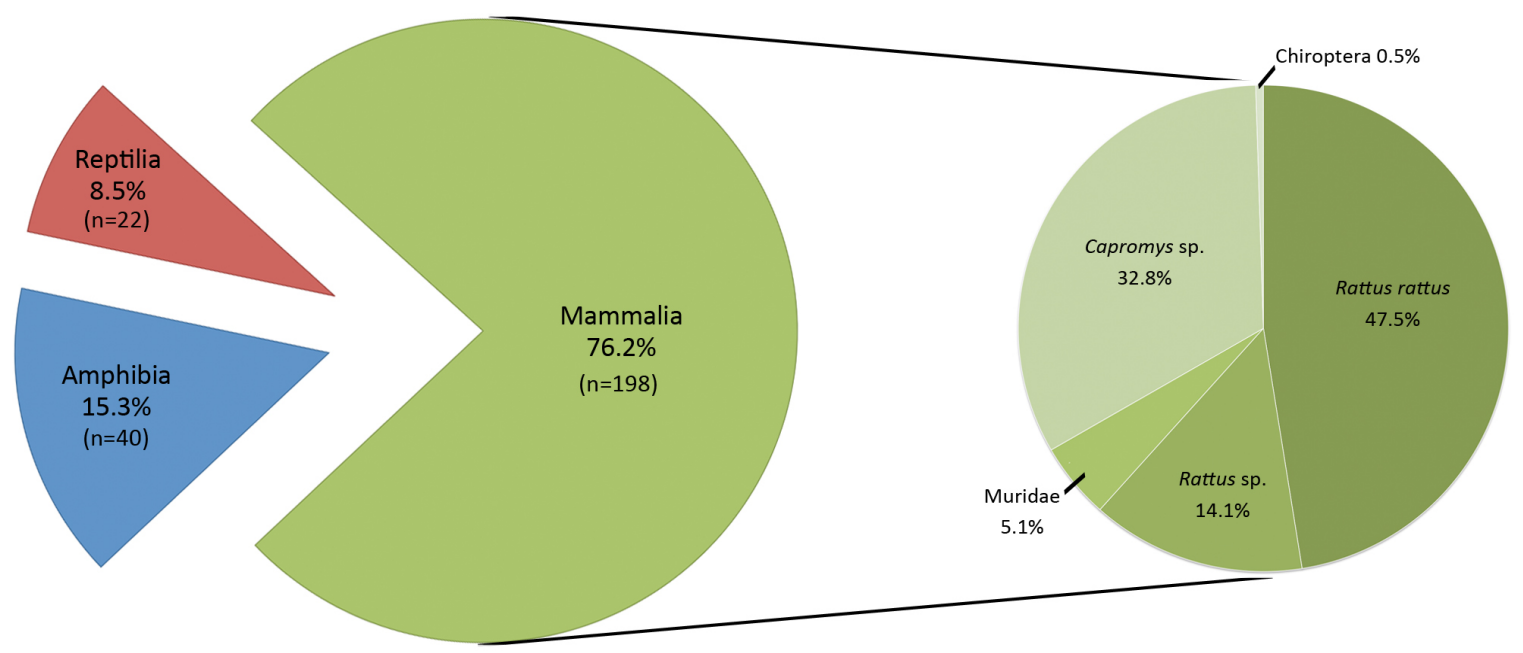

Figure 4: Chart showing faunal composition of the ancient vertebrate remains in Green Cave as established through ZooMS analysis.

\section{Species-Specific Biomarkers}

Capromyid rodents, Geocapromys brownii and Capromys pilorides (reference species), differ subtly in their collagen fingerprints. Though most peaks appear to match in the PMFs of the two species, a single homologous biomarker, COL1A2T54, identified here at $\mathrm{m} / z 1235$ (GEAGAAGPAGPAGPR) and $\mathrm{m} / z 1239$ (GEAGAAGTAGPAGPR) in G. brownii and C. pilorides respectively, can be used to separate these two closely related species (Figure 5). This mass shift of $+4 \mathrm{Da}$ has occurred through the amino acid substitution of proline $(\mathrm{P})$ to threonine $(\mathrm{T})$ - both amino acids that are common in collagen $(\mathrm{I})$ and a substitution that is frequently observed (e.g. Buckley et al., 2009). When comparing the reference PMF for $C$. pilorides to the PMFs of the identified capromyid rodents from Cayman Brac, a peak at $m / z 1239$ is visible in all 65 of the ancient samples. Following the in-depth work of Morgan (1994a) only two species of hutia are known from Cayman Brac: Capromys sp. which is thought to be derived from C. pilorides, and Geocapromys $\mathrm{sp}$. which is thought to be derived from a Cuban form. We therefore conclude the identity of the 65 ancient samples as the extinct, endemic and undescribed Cayman Island Capromys sp. 


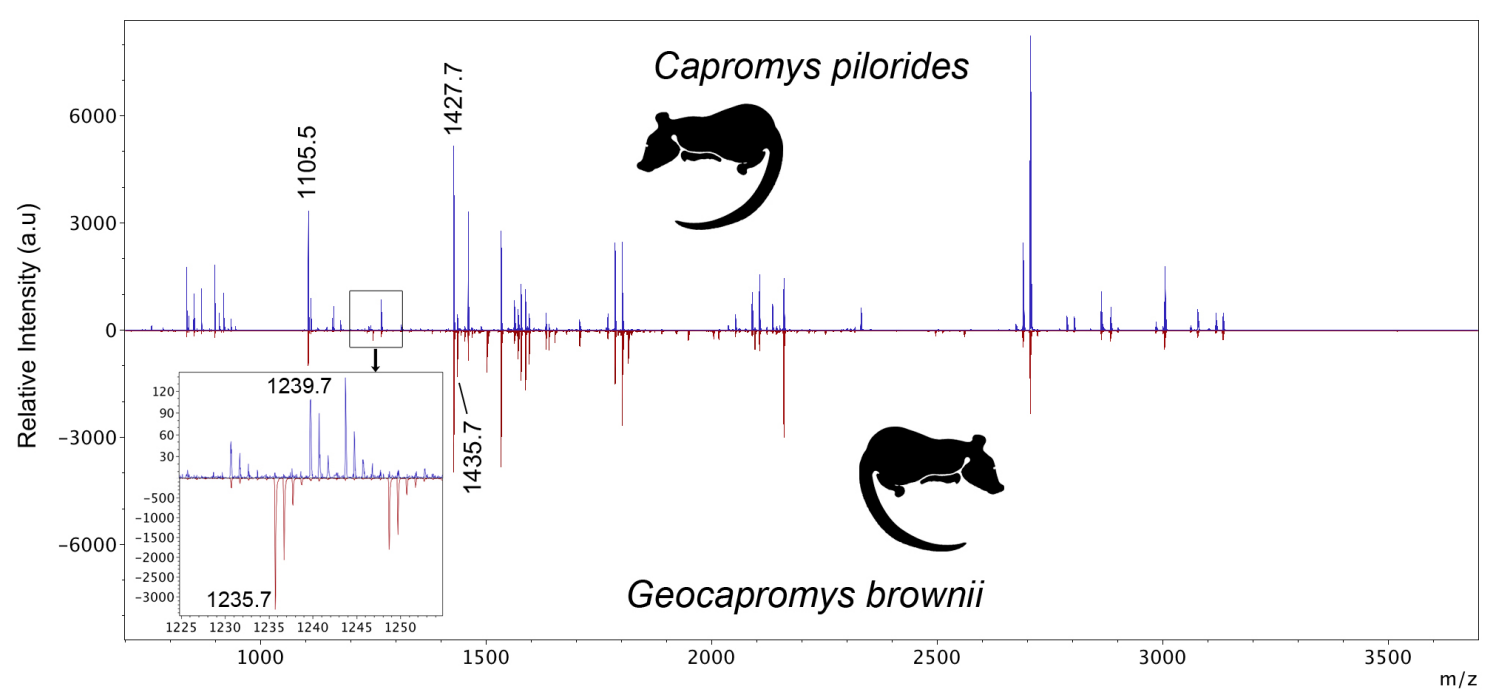

Figure 5: MALDI-MS peptide mass fingerprints showing 10\% ACN fractionations of collagen (I) extracted from reference samples of $C$. pilorides (top) and G. brownii (bottom) following tryptic digest. Inset: Species-specific homologous biomarker at $\mathrm{m} / \mathrm{z}$ 1239 in C. pilorides and $m / z 1235$ in G. brownii.

\section{Faunal Composition in Green Cave}

The majority of specimens from the Green Cave sub-fossil assemblage are murid rodents (introduced; extant) and capromyid rodents (endemic; extinct), with these two families dominating differing chambers of Green Cave. This shift in faunal composition can be observed as the cave system is followed from the entrance to the deepest chamber, chamber 5 . At the cave entrance and within chamber 1 murid rodent remains are dominant, with deeper chambers becoming more concentrated in the remains of Capromys sp. (Figure 6). Therefore, the entrance chamber and chamber 1 are composed primarily of species that are currently introduced and extant on the island, whereas deeper chambers (chambers 2-5) mainly host remains of extinct capromyid rodents. The one exception to this rule is chamber 3 , where a relatively large proportion of remains are identified as Reptilia and less than half are capromyid rodents. Additionally, the proportion of positive compared to failed PMFs varies within each specific cave locality (Supplementary Figure S4). The majority of samples in the entrance chamber and chambers 1-4 were successful in producing PMFs, whereas samples excavated from chamber 5 , including each excavated stratigraphic context (see Table 1), were mostly unsuccessful. All of the samples in the deepest contexts of chamber 5 (context 3, 20-25 $\mathrm{cm}$; and context 4, 25-35 cm) failed to produce PMFs and these trends were also recognized in pilot analyses which included the same cave system by Harvey et al. (2016). 

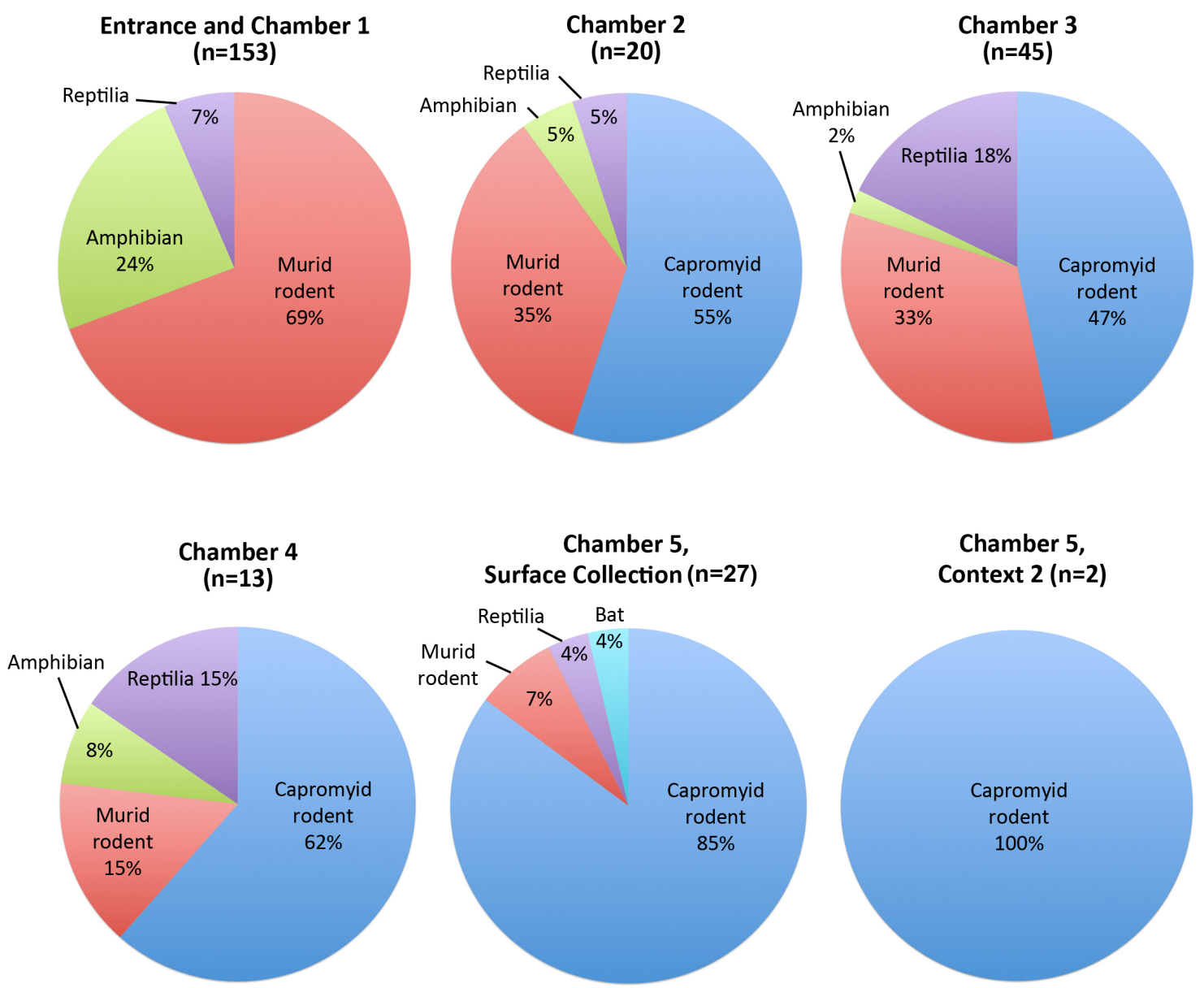

Figure 6: Faunal composition within each distinct region of Green Cave. Percentages expressed as a proportion of the total identifications for each chamber (declared in brackets). Contexts 3 and 4 of chamber 5 are omitted as there are no identifications in these regions due to poor PMFs.

\section{Discussion}

Due to their isolated nature, islands serve as unique 'model systems' for both ecological and evolutionary study (Gillespie et al., 2008; Fitzpatrick and Erlandson, 2018), and this very quality renders them susceptible to endemic species loss. Our approach samples both surficial and sub-surface deposits from Green Cave, Cayman Brac, to constrain temporal changes in the fossil assemblage and also maps the samples spatially within the cave system to resolve any environmental and taphonomic controls on deposition and preservation respectively. The method sub-samples the entire bone assemblage from specific cave locations, rather than focusing on portions of the assemblage that may only be identified using morphological characters. This holistic approach makes use 
of all samples collected, as opposed to a fraction of the potential in the absence of morphological characteristics and/or morphology experts.

\section{Faunal Identifications}

Collagen (I) analyses of faunal assemblages from the Caribbean have not been undertaken previously until this current study. The ZooMS mass spectrometric approach allows visual discrimination between collagen peptides mass fingerprints (PMFs) to aid in zooarchaeological identification and the technique is demonstrated here as effective in achieving faunal identity in bone remains from Green Cave, Cayman Brac (Figure 3; Supplementary Figures S1-3). Successful PMF interrogation has enabled the categorization of all collagen-containing fragmented, degraded and/or matrix-encased bone samples into a definitive order, family, genera or species (Figure 4).

\section{Mammalia}

Collagen fingerprints of all Cayman terrestrial mammal remains can be identified to species level through the determination of a set of biomarkers defining each specific taxon (Figure 3). This 'biomarker database' allows the cataloguing of all terrestrial mammal species on Cayman Brac, which offers key ecological insights considering terrestrial mammals alone contribute to $76 \%$ of the fingerprinted Green Cave assemblage. Refining identification to species level classification is possible in closely related hutia species, $C$. pilorides and G. brownii (Figure 5). Here, the presence of at least one amino acid substitution within the $\sim 2,000$ residue sequence of collagen $(I)$ is not altogether unexpected given that the two taxa diverged in the Late Miocene $(\sim 4.2$ Ma) (Fabre et al., 2014). However, it is not always the case that mammalian species can be separated through collagen $(\mathrm{I})$ analysis following such divergence timeframes. For example, harp seals and grey seals (both of the family Phocidae) diverged approximately 6-7 Ma, (Flynn et al., 2005), yet have collagen PMFs that cannot be readily differentiated (Buckley and Collins, 2011); whereas $R$. rattus and $R$. norvegicus are estimated to have diverged just $2 \mathrm{Ma}$ (Verneau et al., 1998), and whose sequences contain at least one amino acid substitution (Buckley et al., 2016). Although viable estimations can be made with regards to divergence timeframes versus the number of evolution-induced collagen (I) sequence variations, these exceptions to the rule suggest that either one of these factors cannot necessarily be accurately determined by the other. Here, other aspects of biology, such as generation time, may come into play when estimating the frequency of residue substitutions through time in collagen (I).

\section{Chiroptera}

A total of eight bat species are known from Cayman Brac, although only four inhabit the island today. All other species have been extirpated from the island including the region's only endemic form, an undescribed sub-species of Eptesicus fuscus (E. fuscus sp. 
nov.; Family: Vespertilionidae), now extirpated from Cayman Brac though remains present on Grand Cayman. Despite bat skeletal remains making up almost 3\% (31 of 1096) of a sub-fossil assemblage during a previous study of a cave system on Cayman Brac (Morgan, 1994b), only a single bat, Sample 174, was identified from Green Cave and whose PMF did not match either of the two Cayman Brac reference chiropterans tested, Macrotus waterhousii and Erophylla sezekorni (Family: Phyllostomidae). Indeed, all the peptide biomarkers identified in Sample 174 matched the published collagen (I) sequence for $E$. fuscus (BLAST/P). Sample 174 also shares more identical biomarker sequences with the globally widespread genus Myotis sp., also of the Vespertilionidae family, than it does to either of the two Cayman Brac phyllostomids (LC-MS/MS data; see Supplementary Table S4), supporting its identification as vespertilionid. In order to test this hypothesis, bone samples of E. fuscus and also of Tadarida brasiliensis (Family: Molossidae, the third bat family present on Cayman Brac) were acquired for collagen fingerprinting (Supplementary Table S3). The PMF of Sample 174 matches that of reference sample E. fuscus (Figure 7), whereas at least two biomarkers can be seen to differ between E. fuscus and T. brasiliensis (Supplementary Table S4). We therefore conclude that Sample 174 is a specimen of the extirpated vespertilionid bat, E. fuscus sp. nov. As well as highlighting an excellent application of ZooMS, this result provides evidence that Green Cave was a likely roosting location for $E$. fuscus sp. nov. prior to the species' demise on the island. Such knowledge of this local extinction could be used in arguments for the reintroduction of this species; such has been the case with European beaver (Castor fiber) in Britain in the $16^{\text {th }}$ century (Raye, 2015). Due to the extirpation of half of all the bat species known to Cayman Brac, ZooMS faunal screening for bat remains may be effective in the support of future initiatives towards ecological restoration on this island. 


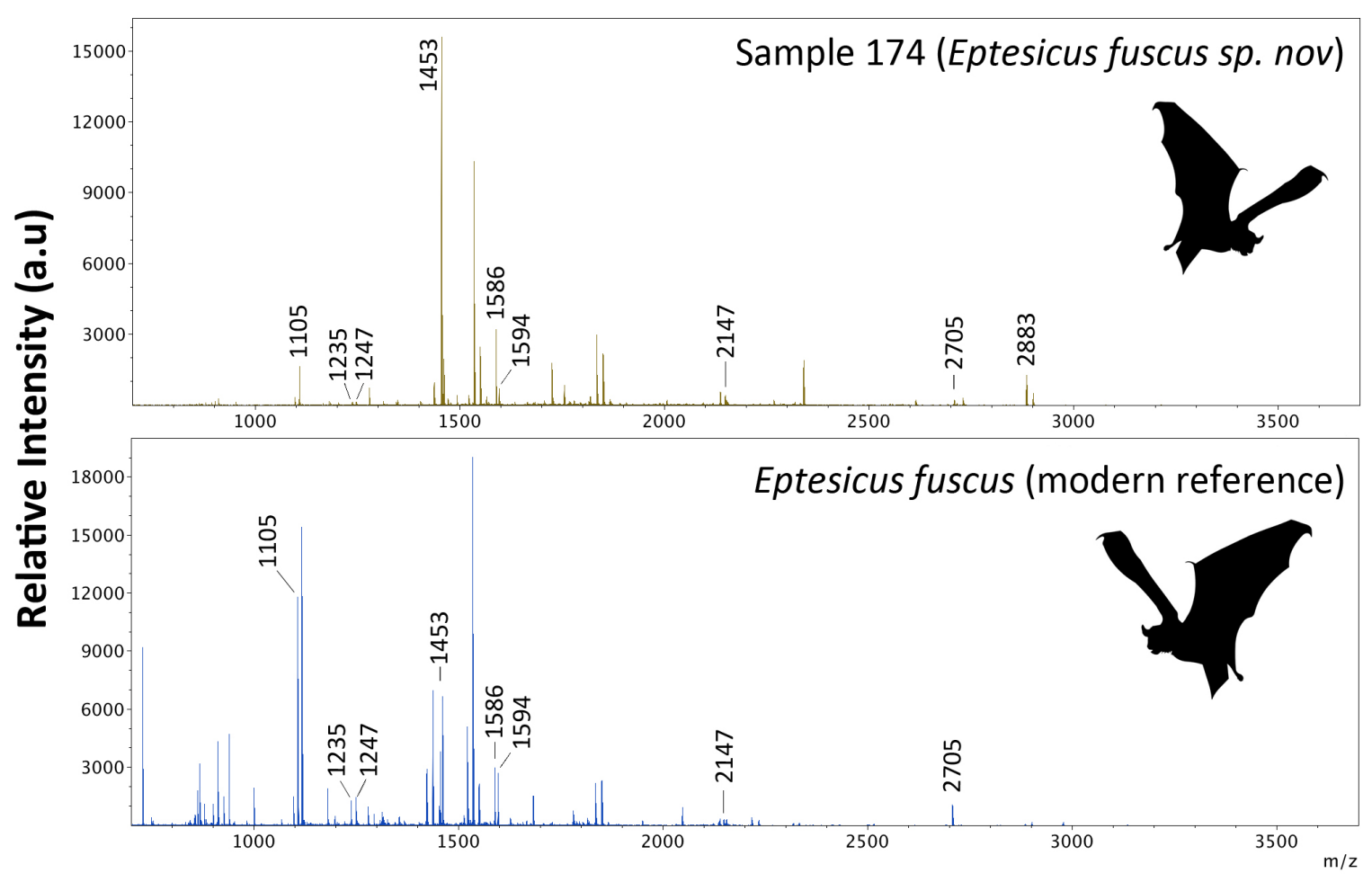

Figure 7: MALDI-MS peptide mass fingerprints showing 10\% ACN fractions of collagen (I) extracted from ancient bone fragment, Sample 174, Eptesicus fuscus sp. nov (top), and a modern reference sample of $E$. fuscus (bottom) following tryptic digest. Visible biomarkers are labeled in each case (see also Supplementary Table S4).

\section{Amphibia}

The collagen (I) PMF from the amphibian reference sample, Bufo viridis (European green toad) shows a clear peak at $m / z 1134$ (Supplementary Figure S3), representing biomarker COL1A1T47 and sequence GAQGPPGPQGPR as derived by LC-MS/MS. Where the COL1A1T47 biomarker is highly conserved at $\mathrm{m} / \mathrm{z} 1105$ (GVQGPPGPAGPR) in all known terrestrial mammals (Buckley et al., 2014), this peptide biomarker appears to be less conserved in amphibians. Only two species of amphibian are native to Cayman Brac, Eleutherodactylus planirostris (greenhouse frog, Leptodactylidae) and Osteopilus septentrionalis (Cuban tree frog, Hylidae). The reference species of tree frog analyzed, Agalychnis callidryas (Family: Hylidae), displays the homologous peptide peak at $m / z$ 1108 (Supplementary Figure S3), representing sequence GAQGPPGPQGAR and highlighting a further amino acid substitution in this species. All 40 samples identified as Amphibia from the Green Cave assemblage have identical PMFs, with the COL1A1T47 biomarker visible at $m / z 1134$. Therefore these samples are not likely to represent the hylid tree frog, O. septentrionalis, and are more likely to be E. planirostris (Anura: Leptodactylidae). The possibility that the Green Cave amphibian remains are from the introduced cane toad Rhinella marina (Anura: Bufonidae), though unlikely, cannot be ruled out at this stage as this bufonid frog species would be expected to have a 
biomarker at $m / z 1134$ as with $B$. viridis. Where $R$. marina has become well established on Grand Cayman in recent times (Edgar, 2010), it has been rarely recorded on Cayman Brac (Echternacht et al., 2011), though as yet its full distribution has not been documented. Ruling out the presence of highly invasive $R$. marina in this cave system would be an important ecological clarification for future studies of this ilk. Overall, this lower level of sequence specificity for a key collagen (I) biomarker that is otherwise highly conserved in the mammals means that the potential for taxonomic refinement to species-level in both species of Amphibia on Cayman Brac is high, and indeed for many amphibian species beyond the confines of this island.

\section{Reptilia}

Identification of the Reptilia requires care due to the sequence variant for collagen (I) biomarker peptide COL1A1T47 (GVQGPAGPPGPR) in iguanids (Cyclura sp. and Sample 71), which is isobaric to the homologous peptide biomarker in mammals (GVQGPPGPAGPR). There are two iguanid species on Cayman Brac, the endemic and critically endangered Cyclura nubila caymanensis and the introduced Iguana iguana. Understanding which of these two species Sample 71 represents would require the acquisition of reference bone samples from each of these two species, and the result may change what we know about the ecology and distribution of these species on Cayman Brac so could be a valuable analysis for a future study. With this one exception, all other samples of Reptilia (birds/reptiles) from Green Cave display the COL1A1T47 biomarker at $m / z$ 1162. This single biomarker is useful in separating the Reptilia from other vertebrate clades in this assemblage, but cannot alone be used to distinguish between birds and non-avian reptiles (with the exception of iguanids). Reptilia specimens from Green Cave exhibit some, though not all, of the avian biomarkers suggested by Buckley et al. (2009), though some of these biomarkers are also expressed in Sample 71, a definitive reptile. It is therefore likely that some of these previously suggested avian biomarkers are also common to many reptiles and further work is required to separate this complex vertebrate order using collagen (I) analysis.

Cayman Brac hosts a diverse repertoire of birds and reptiles, with a total of 32 and 23 species respectively (Seidel and Franz, 1994; Bradley and Rey-Millet, 2013). Acquiring reference samples of each would be an extensive task (particularly as two avian species are globally extinct; Morgan, 1994a) and perhaps would not be the most efficient solution to deriving biomarkers to separate the Cayman birds and reptiles. Here, collagen sequence analysis on Cayman Brac samples, matched to a greater variety of easily accessible modern reference specimens than the scope of this study permits, could be useful in separating the birds from the reptiles, and perhaps also for refinement into family, genus and/or species identity. When such biomarkers are in place, a more detailed understanding of Reptilia composition in the cave system could be achieved, and any ecological causes and effects better understood. 
It is important to note that proposed biomarkers are not necessarily present as the tallest (i.e. most abundant) peaks in a PMF as the relative abundance of a peptide relates to its chemistry [as defined by its amino acid sequence], and consequently how it behaves following ionisation during MALDI-MS. Where collagen (I) concentrations in a bone are reduced due to degradation-as is common in older samples-PMFs are typically poorer, with fewer peaks, a reduction in biomarker visibility and peaks present at lower relative abundance, thereby limiting biomarker resolution. The speed of collagen (I) degradation through time is also related to whole bone surface area, with smaller bone elements from microvertebrates being more vulnerable to faster degradation than larger bones (Collins et al., 2002). Additionally, chemical and/or biological degradation of collagen (I) through time is driven by collagen molecule hydrolysis, reducing the probability of high molecular weight peptides survival over shorter length peptides, as modeled by Collins et al. (1995).

\section{Faunal Composition}

Noticeable differences can be seen in the spatial distribution of taxa within the Green Cave system (Figure 6). Deeper cave chambers (4-5) are comprised primarily of the large, extinct capromyid Capromys sp. whereas chambers nearer the cave entrance host a majority of smaller extant taxa (murid rodents, amphibians and birds/reptiles). There are two explanations to such an arrangement. Firstly, smaller animals are more likely to have been deposited into the cave system through barn owl pellet regurgitation rather than cave habitation (Morgan, 1994a), and as such, barn owls are known to roost on ledges, tucked into the entrance chambers of caves as opposed to deep inside cave systems (Andrews, 1990; Madsen, 2000). A second explanation pertains to the relative age of the bones in the cave systems on Cayman Brac, whereby remains deposited in deeper chambers are typically older than those of entrance chambers. This tendency is assumed here due to the proportions of successful PMFs in each cave region (Supplementary Figure S4), and is also supported by radiocarbon dates achieved in a previous study by Harvey et al. (2016) on Green Cave faunal remains, reporting dates of $609 \pm 26$ radiocarbon years before present (yr BP) (chamber 2), $928 \pm 26 \mathrm{yr} \mathrm{BP}$ (chamber 3), $1588 \pm 26$ yr BP (chamber 4) and $1166 \pm 34$ yr BP (chamber 5). Therefore, the distribution of fauna across the cave system displayed using the criterion of collagen (I) survival alone is perhaps an artifact of preservation bias - a trend not unknown from the literature (Andrews, 1990; Lam and Pearson, 2005). Ultimately, it is probable that larger bone remains in Cayman Brac, such as that of capromyid rodents, will have recoverable collagen (I) for longer than the bones of smaller species of the same age simply as a consequence of their greater surface to volume ratio (Collins et al., 2002; Buckley and Collins, 2011). Of course, frequent bioturbation caused by murid rodents and Caribbean land crabs (Family: Gecarcinidae) in the cave system ensures deeper chambers do not definitively contain older samples than entrance caves, which is likely to explain why murid rodents, reptiles/birds and the solitary bat specimen have been recovered from chamber 5 . 
Green Cave, although one of the larger cave systems on Cayman Brac, may not be the preferred habitat for some species on the island, both past and present. This study has not uncovered any specimens of the extinct eutherian, Nesophontes sp., nor has it found any examples of the introduced rodents, $R$. norvegicus, M. musculus and $D$. punctata. In the case of the former, Morgan (1994a) found remains of Nesophontes in only three caves on Cayman Brac from a total of eight that were excavated; all three of which are located on the north-east coast of the island. Perhaps these species did not inhabit Green Cave, or perhaps they were not present in the hunting range of ancient Tyto alba.

The Central American red agouti, $D$. punctata, is not normally recognized for its cavedwelling behavior though has been found in cave fossil assemblages in Brazil where it has likely been deposited through the act of large predators or scavengers (Victor et al., 2013). With the absence of such predatory species on the Cayman Islands, it is to be expected that $D$. punctata remains would not commonly be found in Cayman cave assemblages, nor were they uncovered in the thorough searches achieved by Morgan (1994a) on both Cayman Brac and Grand Cayman. To date, this species remains unreported on Cayman Brac, and therefore its absence in the assemblage was expected. Due to similar trophic levels, it has been speculated that $D$. punctata would compete with hutia species, Capromys, directly for food and space (Borroto-Páez and Woods, 2012), yet the loss of Capromys and Geocapromys species on Cayman Brac in the likely absence of $D$. punctata requires a separate hypothesis. Elsewhere in the Caribbean, introduced dogs have been known to attack both the Cuban Demarest's hutia ( $C$. pilorides) and the Bahamian hutia (G. ingrahami), evidenced by observed fur remains in excreta (Borroto-Páez and Woods, 2012). Incidentally, dogs have also been blamed for population reduction of the endemic iguanids Cyclura nubila caymanensis (Lewis, 1940), and C. nubila lewisi (Morgan, 1994a), both of which remain critically endangered today (IUCN, 2018). However, remains of canids on the Cayman Islands have neither been recovered from this study nor that of Morgan (1994a), which suggests that the extinction of the Cayman Island hutia species is likely linked to the introduction of invasive murid rodents. The presence of Rattus rattus in the assemblage alongside the absence of the other two prevalent murid rodents on Cayman Brac, R. norvegicus and $M$. musculus, was not an anticipated result. Interestingly, it has been observed on islands in New Zealand that M. musculus directly competes with the two Rattus sp. for food and space, with the former being subordinate to the rat species (Yom-Tov et al., 1999). The high percentage of Rattus sp. in the assemblage therefore explains the lack of $M$. musculus. However, the absence of $R$. norvegicus in the presence of $R$. rattus remains unusual. Research by Moors (1990) shows that $R$. rattus is statistically more likely to inhabit an island when that locality lacks $R$. norvegicus, suggesting competition between the two species that favors $R$. norvegicus. In all cases, it seems the ecology behind murid rodent distribution on Cayman Brac cannot yet be clarified but could be crucial in the understanding of how biodiversity has changed since their introduction to these islands. 


\section{Collagen Analysis: The Wider Context}

The sub-fossil record on the Cayman Islands displays a faunal legacy that traces biodiversity through time. The cave systems provide molecular sanctuaries, preserving vertebrate bone remains beyond the period of human occupation on these islands. Currently, these proteomic tools remain underexplored despite their proven usefulness in both terrestrial (e.g. Buckley et al., 2017) and marine (e.g. Harvey et al., 2018) realms. Our findings here demonstrate collagen analysis as valuable in the reconstruction of paleofaunal assemblage data and in the understanding of how ecosystems have changed as a function of anthropogenic influences. Importantly, this case study presents collagen biomarkers and species-level identifications for a suite of vertebrate families never before studied through collagen fingerprinting, demonstrating the versatility of this technique. This study also provides a comprehensive collagen (I) biomarker 'catalogue' for the identification of terrestrial fauna from Cayman Brac, refining taxonomic identification to species level in terrestrial mammals. Such biomarkers are directly applicable for species identification across the Cayman Islands, into other areas of the Caribbean and beyond. Finally, collagen analysis can harness a wealth of information from sub-fossil assemblages, including the extraction of faunal identity that can be constrained within a temporal framework (Harvey et al., 2016), the applications of which are extensive and wholly relevant to similar threatened environments worldwide. At present, the main limitation of collagen (I) sequencing by soft-ionisation mass spectrometry is the lack of reference collagen (I) PMFs and sequences, a concern also highlighted by Buckley (2013). Overcoming this challenge requires the expansion of publically available protein sequence databases, such as BLAST/P, which in turn depends upon a wider adoption of collagen-based analyses across interdisciplinary fields of science. Despite this hindrance, collagen analysis provides ample opportunities to gain new perspectives on past human impacts to assist in the direct protection of our future. Work in this area is critically important as we begin to formally recognize a departure from the Holocene epoch, into the Anthropocene (e.g. Smith and Zeder, 2013; Dirzo et al., 2014; Waters et al., 2016).

\section{Conclusions}

Current global conservation strategies largely ignore data provided by paleontological and sub-fossil records, despite the fact that they supply an invaluable long-term perspective on ecosystem alterations, such as foreign species invasions. The Caribbean island of Cayman Brac is a remarkable example of an island model system with an array of cave systems that have collected faunal remains through time. The island has been subjected to a multitude of naturally occurring experimental controls (geographical isolation; lack of prehistoric occupation), and a combination of these factors has created a unique research opportunity to improve our understanding of island palaeobiodiversity spanning the boundary of human occupation of the region. The assessment of the sub-fossil assemblage in Green Cave (Cayman Brac) has found the 
majority of vertebrate remains to be introduced and invasive murid rodents, far outnumbering the remains of any other endemic or native species, either extinct or extant. In view of the recent anthropogenically-caused extreme loss of biodiversity on the Cayman Islands, this study showcases the use of a molecular surveying technique to uncover new information on species presence, composition and diversity. A knowledge of past trends diagnosed from fossil assemblages could be critical in the management of environments that are facing similar threats posed by invasive species.

\section{Acknowledgements}

Many thanks go to Gary Morgan (Curator of Vertebrate Paleontology; New Mexico Museum of Natural History) with his help in the identification of bat species Macrotus waterhousii and Erophylla sezekorni from skulls recovered from Cayman Brac. Sincere appreciation is extended to Andrew Kitchener (National Museums Scotland), Johanset Orihuela (Florida International University), Richard Cooke (Smithsonian Tropical Research Institute) and to the Preziosi Lab (University of Manchester) for donations of reference specimens. Thanks also go to the University of Sheffield for access to their vertebrate reference collection, and the University of Manchester's Proteomics Core Facility for access to instrumentation. Credit goes to Tijan Seeley for his help curating the Cayman Brac samples in this study. We also acknowledge the Royal Society for fellowship funding to MB (URF120473) and STFC for their support to PLM (ST/M001814/1). The authors also wish to thank the Department of Environment, Cayman Islands Government, for their support in permitting the fieldwork and excavations in the cave systems on Cayman Brac.

\section{Declaration of conflicting interests}

The authors declare that they have no competing interests.

\section{Author Contributions}

Conceived and designed the experiments: VLH, PLM and MB. Performed the experiments: VLH and MB. Analyzed the data: VLH and MB. VLH wrote the manuscript and designed figures (with the exception of Figure 2 produced by ATC and WIS), with author contributions from MB, VME, PLM, ATC, and WIS. Collected the samples and scanned the cave system: MB, VME, PLM, ATC and WIS. 


\section{References}

Anadón-Irizarry V, Wege DC, Upgren A, et al. (2012) Sites for priority biodiversity conservation in the Caribbean Islands Biodiversity Hotspot. Journal of Threatened Taxa 4: 2806-2844.

Andrews P. (1990) Owls, caves and fossils: predation, preservation and accumulation of small mammal bones in caves, with an analysis of the Pleistocene cave faunas from Westbury-sub-Mendip, Somerset, UK, Chicago: University of Chicago Press.

Borroto-Páez R and Woods CA. (2012) Status and impact of introduced mammals in the West Indies. In: Borroto-Páez R, Woods C and Sergile F (eds) Terrestrial Mammals of the West Indies: Contributions. Florida, USA: Wocahoota Press and Florida Museum of Natural History, pp. 241-258.

Bradley PE and Rey-Millet YJ. (2013) A photographic guide to the birds of the Cayman Islands, London, UK: Christopher Helm Publishers Ltd.

Brooks TM, Mittermeier RA, Mittermeier CG, et al. (2002) Habitat loss and extinction in the hotspots of biodiversity. Conservation Biology 16: 909-923.

Buckley M. (2013) A molecular phylogeny of Plesiorycteropus reassigns the extinct mammalian order 'Bibymalagasia'. PLoS One 8: e59614.

Buckley M. (2016) Species identification of bovine, ovine and porcine type 1 collagen; comparing peptide mass fingerprinting and LC-based proteomics methods. International Journal of Molecular Sciences 17: 445.

Buckley M, Collins M, Thomas-Oates J, et al. (2009) Species identification by analysis of bone collagen using matrix-assisted laser desorption/ionisation time-of-flight mass spectrometry. Rapid Communications in Mass Spectrometry 23: 38433854.

Buckley M and Collins MJ. (2011) Collagen survival and its use for species identification in Holocene-lower Pleistocene bone fragments from British archaeological and paleontological sites. Antiqua 1: 1.

Buckley M, Fariña RA, Lawless C, et al. (2015) Collagen sequence analysis of the extinct giant ground sloths Lestodon and Megatherium. PLoS One 10: e0139611.

Buckley M, Fraser S, Herman J, et al. (2014) Species identification of archaeological marine mammals using collagen fingerprinting. Journal of Archaeological Science 41: 631-641.

Buckley M, Gu M, Shameer S, et al. (2016) High-throughput collagen fingerprinting of intact microfaunal remains; a low-cost method for distinguishing between murine rodent bones. Rapid Communications in Mass Spectrometry 30: 1-8.

Buckley M, Harvey VL and Chamberlain AT. (2017) Species identification and decay assessment of Late Pleistocene fragmentary vertebrate remains from Pin Hole Cave (Creswell Crags, UK) using collagen fingerprinting. Boreas.

Buckley M and Kansa SW. (2011) Collagen fingerprinting of archaeological bone and teeth remains from Domuztepe, South Eastern Turkey. Archaeological and Anthropological Sciences 3: 271-280. 
Buckley M, Kansa SW, Howard S, et al. (2010) Distinguishing between archaeological sheep and goat bones using a single collagen peptide. Journal of Archaeological Science 37: 13-20.

Collins MJ, Nielsen-Marsh CM, Hiller J, et al. (2002) The survival of organic matter in bone: a review. Archaeometry 44: 383-394.

Collins MJ, Riley MS, Child AM, et al. (1995) A basic mathematical simulation of the chemical degradation of ancient collagen. Journal of Archaeological Science 22: 175-183.

Cooke SB, Dávalos LM, Mychajliw AM, et al. (2017) Anthropogenic extinction dominates Holocene declines of West Indian mammals. Annual Review of Ecology, Evolution, and Systematics 48: 301-327.

Cottrell JS and London U. (1999) Probability-based protein identification by searching sequence databases using mass spectrometry data. Electrophoresis 20: 35513567.

Dávalos LM and Turvey ST. (2012) West Indian mammals: The old, the new, and the recently extinct. In: Patterson $B$ and Costa $L$ (eds) Bones, clones, and biomes: an extended history of recent neotropical mammals. Chicago, USA: University of Chicago Press, pp. 157-202.

Dirzo R, Young HS, Galetti M, et al. (2014) Defaunation in the Anthropocene. Science 345: 401-406.

Drewett PL, Scudder SJ and Quitmyer IR. (2000) Unoccupied Islands? The Cayman Islands. In: Drewett PL (ed) Prehistoric settlements in the Caribbean: fieldwork in Barbados, Tortola and the Cayman Islands. London: Archetype Publications for the Barbados Museum and Historical Society, 5-16.

Echternacht A, Burton F and Blumenthal J. (2011) The amphibians and reptiles of the Cayman Islands: Conservation issues in the face of invasions. In: Hailey A, Wilson B and Horrocks J (eds) Conservation of Caribbean Island Herpetofaunas. Leiden, Boston: Brill, pp. 129-147.

Edgar P. (2010) The amphibians and reptiles of the UK overseas territories, crown dependencies and sovereign base areas: species inventory and overview of conservation and research priorities. Amphibian and Reptile Conservation, Boscombe, UK.

Fabre P-H, Vilstrup JT, Raghavan M, et al. (2014) Rodents of the Caribbean: origin and diversification of hutias unravelled by next-generation museomics. Biology Letters 10: 20140266.

Fitzpatrick SM. (2015) The Pre-Columbian Caribbean: Colonization, population dispersal, and island adaptations. PaleoAmerica 1: 305-331.

Fitzpatrick SM and Erlandson JM. (2018) Island Archaeology, Model Systems, the Anthropocene, and How the Past Informs the Future. The Journal of Island and Coastal Archaeology 13: 283-299.

Fitzpatrick SM and Keegan WF. (2007) Human impacts and adaptations in the Caribbean Islands: an historical ecology approach. Earth and Environmental Science Transactions of the Royal Society of Edinburgh 98: 29-45. 
Flynn JJ, Finarelli JA, Zehr S, et al. (2005) Molecular phylogeny of the Carnivora (Mammalia): assessing the impact of increased sampling on resolving enigmatic relationships. Systematic Biology 54: 317-337.

Gillespie RG, Claridge EM and Roderick GK. (2008) Biodiversity dynamics in isolated island communities: interaction between natural and human mediated processes. Molecular Ecology 17: 45-57.

Giovas CM, LeFebvre MJ and Fitzpatrick SM. (2012) New records for prehistoric introduction of Neotropical mammals to the West Indies: evidence from Carriacou, Lesser Antilles. Journal of Biogeography 39: 476-487.

GISD. (2016) Global Invasive Species Database (http://www.issg.org/database)

Guimaraes S, Fernandez-Jalvo Y, Stoetzel E, et al. (2016) Owl pellets: a wise DNA source for small mammal genetics. Journal of Zoology 298: 64-74.

Harvey VL, Daugnora L and Buckley M. (2018) Species identification of ancient Lithuanian fish remains using collagen fingerprinting. Journal of Archaeological Science 98: 102-111.

Harvey VL, Egerton VM, Chamberlain AT, et al. (2016) Collagen fingerprinting: A new screening technique for radiocarbon dating ancient bone. PLoS One 11: e0150650.

IUCN. (2018) The IUCN Red List of Threatened Species. Version 2018-1. available at http://www.iucnredlist.org.

Jones B. (1992) Void-filling deposits in karst terrains of isolated oceanic islands: a case study from Tertiary carbonates of the Cayman Islands. Sedimentology 39: 857876.

Lam YM and Pearson OM. (2005) Bone density studies and the interpretation of the faunal record. Evolutionary Anthropology: Issues, News, and Reviews 14: 99-108.

Lewis CB. (1940) The Cayman Islands and marine turtle. In: Grant C (ed) The Herpetology of the Cayman Islands, Bulletin of the Institute of Jamaica Science Series. 56-65.

MacPhee RDE, Flemming C and Lunde DP. (1999) "Last occurrence" of the Antillean insectivoran Nesophontes: new radiometric dates and their interpretation. American Museum of Natural History 3261: 1-20.

Madsen DB. (2000) Late quaternary paleoecology in the Bonneville Basin, Utah, USA: Utah Geological Survey.

Matisoo-Smith E and Allen JS. (2001) Name that rat: Molecular and morphological identification of Pacific rodent remains. International Journal of Osteoarchaeology 11: 34-42.

Moors P. (1990) Norway rat. In: King C (ed) The Handbook of New Zealand Mammals. Oxford, UK: Oxford University Press, pp. 192-206.

Morgan GS. (1994a) Late Quaternary fossil vertebrates from the Cayman Islands. In: Brunt $\mathrm{M}$ and Davies J (eds) The Cayman Islands: Natural history and biogeography. Netherlands: Springer, pp. 465-508.

Morgan GS. (1994b) Mammals of the Cayman Islands. In: Brunt M and Davies J (eds) The Cayman Islands: Natural history and biogeography. Netherlands: Springer, pp. 435-463. 
Morgan GS and Woods CA. (1986) Extinction and the zoogeography of West Indian land mammals. Biological Journal of the Linnean Society 28: 167-203.

Moyne WEGB. (1938) Atlantic Circle, Glasgow, UK: Blackie \& Son Ltd.

Myers N, Mittermeier RA, Mittermeier CG, et al. (2000) Biodiversity hotspots for conservation priorities. Nature 403: 853-858.

Patton TH. (1966) Occurrence of fossil vertebrates on Cayman Brac. Caribbean Journal of Science 6: 181.

Raye L. (2015) The early extinction date of the beaver (Castor fiber) in Britain. Historical Biology 27: 1029-1041.

Rybczynski N, Gosse JC, Harington CR, et al. (2013) Mid-Pliocene warm-period deposits in the High Arctic yield insight into camel evolution. Nature Communications 4: 1550.

Schmidt-Schultz TH and Schultz M. (2004) Bone protects proteins over thousands of years: extraction, analysis, and interpretation of extracellular matrix proteins in archeological skeletal remains. American Journal of Physical Anthropology 123: 30-39.

Seidel M and Franz R. (1994) Amphibians and reptiles (exclusive of marine turtles) of the Cayman Islands. In: Brunt M and Davies J (eds) The Cayman Islands. New York, USA: Springer, pp. 407-433.

Smith BD and Zeder MA. (2013) The onset of the Anthropocene. Anthropocene 4: 8-13.

Smith ML, Hedges SM, Buck W, et al. (2004) Caribbean islands. In: Mittermeier R, da Fonseca, G., Hoffman, M., Pilgram J., Brooks, T., Gill, P., Mittermeier, C., Lamoreux, J. (ed) Hotspots revisited: Earth's biologically richest and most threatened terrestrial ecoregions. Chicago: University of Chicago Press, 112-118.

Smith RC. (2000) The maritime heritage of the Cayman Islands, Florida, USA: University Press of Florida.

Steadman DW, Franz R, Morgan GS, et al. (2007) Exceptionally well preserved late Quaternary plant and vertebrate fossils from a blue hole on Abaco, The Bahamas. Proceedings of the National Academy of Sciences 104: 19897-19902.

Steadman DW, Martin PS, MacPhee RDE, et al. (2005) Asynchronous extinction of late Quaternary sloths on continents and islands. Proceedings of the National Academy of Sciences of the United States of America 102: 11763-11768.

Stokes AV and Keegan WF. (1996) A reconnaissance for prehistoric archaeological sites on Grand Cayman. Caribbean Journal of Science 32: 425-430.

Turvey ST and Fritz SA. (2011) The ghosts of mammals past: biological and geographical patterns of global mammalian extinction across the Holocene. Philosophical Transactions of the Royal Society of London B: Biological Sciences 366: 25642576.

Turvey ST, Oliver J, Storde YN, et al. (2007) Late Holocene extinction of Puerto Rican native land mammals. Biology Letters 3: 193-196.

Upham NS. (2017) Past and present of insular Caribbean mammals: understanding Holocene extinctions to inform modern biodiversity conservation. Journal of Mammalogy 98: 913-917. 
Verneau O, Catzeflis F and Furano AV. (1998) Determining and dating recent rodent speciation events by using L1 (LINE-1) retrotransposons. Proceedings of the National Academy of Sciences 95: 11284-11289.

Victor P, Oliveira A, Ribeiro M, et al. (2013) Late Quaternary Caviomorph Rodents (Rodentia: Hystricognathi) from Ceará State, Northern Brazil. Journal of Cave and Karst Studies 75: 81-91.

Waters CN, Zalasiewicz J, Summerhayes C, et al. (2016) The Anthropocene is functionally and stratigraphically distinct from the Holocene. Science 351: aad2622-26212610.

Williams N. (1992) A history of the Cayman Islands, Bournemouth, Dorset: Bourne Press Ltd.

Wilson SM. (2007) The archaeology of the Caribbean: Cambridge University Press. Wright VP and Wilson R. (1987) A Terra Rossa-like paleosol complex from the Upper Jurassic of Portugal. Sedimentology 34: 259-273.

Yom-Tov Y, Yom-Tov S and Moller H. (1999) Competition, coexistence, and adaptation amongst rodent invaders to Pacific and New Zealand islands. Journal of Biogeography 26: 947-958. 